O. Ye. Fartushna1, H.V. Palahuta2', S.K. Yevtushenko ${ }^{3}$

${ }^{1}$ Ukrainian Military Medical Academy, Kyiv, Ukraine

${ }^{2}$ Uzhhorod National University, Regional Clinical Center of Neurosurgery and Neurology, Uzhhorod, Ukraine ${ }^{3}$ Kharkiv Medical Academy of Postgraduate Education, Kharkiv, Ukraine

\title{
Neurological and neuropsychiatric manifestations and complications of SARS-CoV-2 infection: a narrative review and a case presentation in a previously healthy young white adult
}

\begin{abstract}
Background. As the second wave of COVID-19 occurred, it has become clear that a novel coronavirus (SARS-CoV-2), which has consequently sparked a global pandemic, was evolved into wide-ranging multi-organ disease. However, neurological features of COVID-19 infection, especially in young previously healthy adults, have not been widely reported. We aimed to provide a narrative review of the neurological and neuropsychiatric manifestations and complications of SARS-CoV-2, supported with a clinical case presentation. Materials and methods. A comprehensive electronic literature search was performed on Scopus, PubMed, Embase, Cochrane database, World Health Organization database, Ovid, and Google Scholar in accordance with Preferred Reporting Items for Systematic Reviews and Meta-analysis guidelines to identify the articles that discussed the neurological and neuropsychiatric presentations of SARS-CoV-2/COVID-19. The neurological manifestations and complications of COVID-19 are illustrated with the clinical case presentation in a previously healthy white young adult. Results and conclusions. Neurological and neuropsychiatric manifestations and complications of SARS-CoV-2 infection range from mild symptoms, such as headache, to catastrophic symptoms, including but not limited to delirium, manic episodes, schizophrenia, stroke, acute hemorrhagic necrotizing encephalopathy, transverse myelitis, encephalitis, meningitis, and Guillain-Barré syndrome. We provided a narrative review of the neurological and neuropsychiatric manifestations and complications of SARS-CoV-2 infection, illustrated with the clinical case presentation in a previously healthy white young adult.
\end{abstract}

Keywords: COVID-19; SARS-CoV-2; acute myelitis; neurological presentations; neuropsychiatric presentations; complications; case report; review

\section{Introduction}

The morbidity and mortality of the global community due to the outbreak of novel coronavirus disease 2019 (COVID-19), caused by a highly transmittable viral infection, severe acute respiratory syndrome coronavirus 2 (SARSCoV-2), is increasing dramatically. On March 11, 2020, the World Health Organization characterized COVID-19 as a pandemic, pointing to over 3 million cases and 207,973 deaths in 213 countries and territories [1]. As of January 6,
2021, the COVID-19 pandemic has resulted in more than 87.6 million confirmed cases worldwide and over 1.9 million deaths [2]. It is the largest and most severe pandemic since the 1918 influenza pandemic [3].

The COVID-19 pandemic has not only become the greatest public health crisis of 2020 but has also caused the largest global recession in history, with more than a third of the global population at the time being placed on lockdown [4]. Lockdown froze the economies with unprecedented

() «Міжнародний неврологічний журнал» / «International Neurological Journal» («Meždunarodnyj nevrologičeskij) žurnal»), 2021

(с) Видавець Заславський 0.Ю. / Publisher Zaslavsky 0.Yu., 2021

Для кореспонденції: Фартушна Олена Євгенівна, лікар-невролог, магістр медицини, кандидат медичних наук, старший викладач кафедри авіаційної, морської медицини та психофізіології, Українська військово-медична академія, вул. Мельникова, 24, м. Київ, 04050, Україна; e-mail: olena.y.fartushna@gmail.com

For correspondence: Olena Ye. Fartushna, MD, M.Med.D, Ph.D., clinical neurologist, senior lecturer of the Department of Aviation, Marine Medicine and Psychophysiology, Ukrainian Military Medical Academy, Melnikova st., 24, Kyiv, 04050, Ukraine; e-mail: olena.y.fartushna@gmail.com 
force and speed. Worldwide, 660 million workers lost their jobs, 38 million have filed for unemployment insurance during the pandemic. A record 3.28 million Americans applied for unemployment benefits, the highest number ever recorded [5].

The primary manifestations of COVID-19 are respiratory. However, it has become clear that SARS-CoV-2 can affect multiple parts of the body, including the nervous system. Despite that, neurological features of COVID-19 infection, especially in young previously healthy patients, have not been widely reported and fully investigated.

The purpose of the study: to provide a comprehensive narrative review of the neurological and neuropsychiatric manifestations and complications of SARS-CoV-2 infection, illustrated with the clinical case presentation of neurological features of COVID-19 infection in a previously healthy young white adult.

\section{Materials and methods}

A comprehensive electronic literature search was accomplished on Scopus, PubMed, Embase, Cochrane database, World Health Organization database, Ovid, and Google Scholar in accordance with Preferred Reporting Items for Systematic Reviews and Meta-analysis guidelines to identify the articles that discussed the neurological and neuropsychiatric presentations, manifestations, and complications of SARS-CoV-2/COVID-19. The applicable articles are cited and referenced. No limit placed on publication time or the language of the article.

Studies were included if they have reported specific outcomes on any aspects of neurological symptoms in relation to COVID-19; the main exclusion criteria were commentary, editorials, narrative reviews with no reports on case outcomes or treatment method. Articles, reported non-specific neurological symptoms in COVID-19 patients, such as dizziness, headache, fatigue, and myalgia, which are all likely to be caused by the systemic condition, as well as those that were reporting worsening neurological symptoms, such as impaired consciousness that could be fully accounted for by sedation during ventilation, were also excluded. All the re-levant articles were identified and screened by two authors (O. Fartushna and H. Palahuta), and disagreements were resolved by consensus and involvement of senior author (S. Yevtushenko); the results are summarized narratively.

We provided a complex clinical, neurological, laboratory, and instrumental analysis of manifestations and complications of SARS-CoV-2 infection in a previously healthy young white adult, admitted to the Regional Clinical Center of Neurosurgery and Neurology, the city of Uzhhorod, Ukraine.

\section{Results and discussion}

The clinical spectrum of the SARS-CoV-2 infection appears to be wide, including asymptomatic infection, mild upper respiratory tract illness, and severe viral pneumonia with respiratory failure, and death [6, 7]. Furthermore, various complications beyond the respiratory system, such as acute myocardial injury, acute kidney injury, gastrointestinal, liver, heart, skin injuries, neurological, and neuropsychiatric presentations have been reported [8-16]. The involvement of the nervous system in COVID-19 patients may be related to poor prognosis and disease worsening.

We analyzed, systemized, and summarized all relevant specific neurological and neuropsychiatric presentations, manifestations, and complications of SARS-CoV-2 infection that are reported in medical articles as of January 7 , 2021 (Table 1).

The neurological and neuropsychiatric manifestations, presentations, and complications of SARS-CoV-2 infection include a wide range of symptoms and diseases from mild to severe. Articles, reported non-specific neurological symptoms in COVID-19 patients, such as dizziness, headache, fatigue, and myalgia, which are all likely to be caused by the systemic condition, as well as those reported worsening neurological symptoms, such as impaired consciousness that could be fully accounted for by sedation during ventilation, were excluded and are not analyzed in this article.

\section{Neurological presentations of SARS-CoV-2}

In COVID-19, both central and peripheral nervous systems can be affected. Reports are emerging of neurological presentations of SARS-CoV-2, which range from mild symptoms, such as headache, to catastrophic symptoms, including but not limited to stroke, acute hemorrhagic nec-

Table 1. Neurological and Neuropsychiatric presentations of SARS-CoV-2 infection

\begin{tabular}{|l|l|l|}
\hline \multicolumn{2}{|c|}{ Neurological involvement } & \multirow{2}{*}{ Neuropsychiatric involvement } \\
\cline { 1 - 2 } Dizziness & Peripheral nervous system & \\
Headache & Hypogeusia & Delirium \\
Acute cerebrovascular disease & Hyposmia & Agitation \\
Impaired consciousness & Neuralgia & Confusion \\
Transverse myelitis & Guillian-Barré syndrome & Anxiety \\
Acute hemorrhagic necrotizing encephalopathy & Skeletal muscle injury & Depression \\
Encephalopathy & & Post-traumatic stress disorder \\
Encephalitis & & Behavioral disturbances \\
Epilepsy & & Acute psychosis \\
Ataxia & & Manic disorders \\
Ischemic stroke & & Paranoia \\
Hemmorhagic stroke & & Bipolar disorder \\
Ataxia & & Schizophrenia \\
Gait disturbances & & \\
\hline
\end{tabular}


rotizing encephalopathy, delirium, transverse myelitis, encephalitis/meningitis, and Guillain-Barré syndrome [17-20]. Moreover, in some cases, the neurological manifestations can precede typical respiratory presentation like fever and cough. It was suggested that SARS-CoV-2 can cause neural damage because of direct viral invasion, through hypoxic and immune-mediated pathways, and cytokine storm $[3,6]$.

\section{Central nervous system presentations of SARS-CoV-2}

The central nervous system manifestations and complications of COVID-19 include, but are not limited to headache, dizziness, epilepsy, ataxia, meningitis, encephalitis, acute hemorrhagic necrotizing encephalopathy, acute demyelinating encephalomyelitis, impaired consciousness, and stroke [19-21].

In some studies, encephalopathy is reported in $40 \%$ of COVID-19 patients [18]. The acute cerebrovascular diseases are also emerging as an important manifestation of COVID-19, with cohort studies reporting stroke in 2-6\% of patients hospitalized with COVID-19 [3]. Several reports of acute myelitis associated with COVID-19 infection have been published in the literature, in which COVID-19 is associated with the onset of acute myelitis as a neurological complication [22-27].

Peripheral nervous system and muscle disease presentations of $S A R S-C o V-2$

Reported peripheral nervous system manifestations and complications of COVID-19 include skeletal damage, anosmia, chemosensory dysfunction, and Guillain-Barré syndrome.

In a recent multi-center European study of 417 COVID-19 patients, $85.6 \%$ of patients were diagnosed with olfactory dysfunction and $88.8 \%$ of patients reported gustatory disorders. Around $72.6 \%$ of patients recovered their olfactory functions within the first 8 days [28]. It is believed that anosmia and dysgeusia occurred since the SARS-CoV-2 virus can directly enter the nervous system via the olfactory tract or bloodstream at a pro-inflammatory stage of the disease $[6,18,29]$.

Few cases of COVID-19 associated with Guillain-Barré syndrome, as well as polyneuropathy and Miller Fisher syndrome have been reported [30, 31]. Muscle injury and rhabdomyolysis due to COVID-19 have also been reported [32].

\section{Neuropsychiatric presentations of SARS-CoV-2}

Patients with SARS-CoV-2 show higher manifestations of depression, anxiety, and post-traumatic stress disorder symptoms when compared with non-COVID controls [33]. Delirium, encephalopathy, and acute behavioral changes are common neuropsychiatric signs of COVID-19. Recently, a case report showed that manic-like symptoms might be a delayed response to SARS-CoV-2 in patients with no history of psychiatric illness [34].

Neuropsychiatric presentations of COVID-19 are directly related to an increase in peripheral immunological markers, the severity of infection, and the case fatality rate. Unmitigated neuroinflammation has been noted to underlie not only the severe respiratory complications of the disease but is also present in a range of neuropsychiatric illnesses $[35,36]$.

Health care providers should be aware that, apart from respiratory symptoms, neurological and psychiatric symptoms can manifest in patients with COVID-19. It has been also suggested that the long-term effect of the neuroinvasive nature of COVID-19 may increase the risk of neurodegenerative disease, like multiple sclerosis, chronic encephalopathies, neuromuscular disorders, neuropathies, demyelinating and degenerative conditions occurring a long time after the initial presentation, as it was reported to be after the SARS and MERS outbreaks [37, 38].

\section{Clinical case presentation Neurological manifestations of SARS-CoV-2}

A previously healthy young white man presented to his primary care physician complaining of fatigue, mild headache, moderate low back pain, sub-febrile temperature, loss of taste (dysgeusia) and smell (anosmia) for the past few days. He stated that symptoms occurred gradually. The patient is a student in his middle twenties. He stated that he is living with his family and was in close contact with his family and friends. Suspecting COVID-19, the primary care physician performed an X-ray of the chest that showed no pathology. The patient was recommended to self-quarantine for 14 days, rest and stay hydrated, monitor the symptoms carefully, and if symptoms get worse, call the health care provider immediately. The symptoms disappeared spontaneously in 14 days.

\section{Neurological complications of SARS-CoV-2}

On the $20^{\text {th }}$ day from the time of loss of smell and taste, the patient developed weakness in his legs and began to experience difficulty urinating. Over the next 7 days, sub-febrile condition and pain in the lumbar and thoracic spine were noted. This was accompanied by progressive weakness of the lower extremities, difficulty walking, and constipation. The patient applied to the emergency department of the Regional Clinical Center of Neurosurgery and Neurology, Uzhhorod, Ukraine.

On physical examination, he is a muscular, thickset normosthenic individual with a healthy appearance and no fever. His heart rate was $65 / \mathrm{min}$, respiratory rate was $16 / \mathrm{min}$, and blood pressure was 120/75 mm Hg in both arms. Lung auscultation reveals no pathology. Cardiac auscultation detects no rubs or murmurs. He was not taking any medications prior to admission. Clinical neurological examination revealed decreased muscle strength and tone, hyporeflexia, decreased proprioception of the lower extremities, and paresthesia on both sides from the Th9 level. No pathological reflexes were found. The patient was hospitalized for further examination and treatment.

His general blood tests as well as renal and liver function laboratory results were normal. MRI of the spine showed a segment of increased T2 signal in the center of the spinal cord at the Th11-Th12 level. MRI of the brain and orbits revealed no abnormalities. Cerebrospinal fluid showed increased protein levels and lymphocytic pleocytosis. A serologic blood test for SARS-CoV-2 showed recent infection 
(presence of SARS-CoV-2/IgG as determined by internal immunofluorescence antibody testing). Antibodies to antimyelin-associated glycoprotein IgM and IgG to optic neuromyelitis were negative in serum.

Corticosteroid treatment led to full recovery within a week of hospitalization. The patient was discharged home. One-month follow-up revealed no symptoms of recurrence or any pathology.

\section{Conclusions}

Notwithstanding, the COVID-19 primarily affects the respiratory and cardiovascular systems, neurological involvements are not uncommon and can result in serious complications if not detected and managed early. Neurological presentations of SARS-CoV-2 infection in some cases precede the respiratory symptoms or may be the only symptoms in COVID-19 patients. Neurological and neuropsychiatric manifestations and complications of SARSCoV-2 infection range from mild symptoms, such as headache, to catastrophic symptoms, including stroke, acute hemorrhagic necrotizing encephalopathy, encephalopathy, delirium, severe agitation, manic episodes, schizophrenia, transverse myelitis, encephalitis/meningitis, and GuillainBarré syndrome.

We present a narrative review of the neurological manifestations and complications of COVID-19, accompanied by a clinical case report, to raise awareness about possible neurological diseases, resulting from this novel SARS-CoV-2 infection.

Conflicts of interests. Authors declare the absence of any conflicts of interests and their own financial interest that might be construed to influence the results or interpretation of their manuscript.

Author contributions: Olena Ye. Fartushna - article concept and design, data acquisition, interpretation of data, literature search and overview, drafting the article, critical revision of the manuscript for important intellectual content; Hanna V. Palahuta - study concept and design, data acquisition, interpretation of the data, literature search and overview, critical revision of the manuscript for important intellectual content; Stanislav K. Yevtushenko - study concept and design, interpretation of the data, literature overview, critical revision of the manuscript for important intellectual content.

\section{References}

1. World Health Organization. WHO Director-General's opening remarks at the media briefing on COVID-19 - 11 March 2020. Accessed at www.who.int/dg/speeches/detail/who-director-general-s-opening-remarks-at-the-media-briefing-on-covid19---11-march-2020

2. Johns Hopkins Coronavirus Resource Center. Accessed at https://coronavirus.jhu.edu/map.html

3. Ellul M.A., Benjamin L., Singh B. et al. Neurological associations of COVID-19. Lancet Neurol. 2020. 19 (9). 767-783. doi: 10.1016/S1474-4422(20)30221-0.

4. Yousfi N., Bragazzi N.L., Briki W., Zmijewski P., Chamari K. The COVID-19 pandemic: how to maintain a healthy immune system during the lockdown - a multidisciplinary approach with special focus on athletes. Biol. Sport. 2020. 37 (3). 211-216. doi: 10.5114/ biolsport.2020.95125.

5. Rothwell J. The effects of COVID-19 on international labor markets: An update. Middle Class Memos (May 2020). Accessed: www.brookings.edu/research/the-effects-of-covid-19-on-international-labor-markets-anupdate.

6. Wu Y., Xu X., Chen Z. et al. Nervous system involvement after infection with COVID-19 and other coronaviruses. Brain Behav. Immun. 2020. 87. 18-22. doi: 10.1016/j.bbi.2020.03.031.

7. Phua J., Weng L., Ling L. et al. Asian Critical Care Clinical Trials Group. Intensive care management of coronavirus disease 2019 (COVID-19): challenges and recommendations. Lancet Respir. Med. 2020. 8 (5). 506-517. doi: 10.1016/S2213-2600(20)30161-2.

8. Zhou F., Yu T., Du R., Fan G., Liu Y., Liu Z. et al. Clinical course and risk factors for mortality of adult inpatients with COVID-19 in Wuhan, China: a retrospective cohort study. Lancet. 2020. 395. 1054-62. doi: 10.1016/S0140-6736(20)30566-3.

9. Guan W.J., Ni Z.Y., Hu Y., Liang W.H., Ou C.Q., He J.X. et al. Clinical characteristics of coronavirus disease 2019 in China. N. Engl. J. Med. 2020. 382. 1708-20. doi: 10.1056/NEJMoa2002032.

10. Clerkin K.J., Fried J.A., Raikhelkar J., Sayer G., Griffin J.M., Masoumi A. et al. Coronavirus disease 2019 (COVID-19) and cardiovascular disease. Circulation. 2020. 141. 1648-55. doi: 10.1161/ CIRCULATIONAHA.120.046941.

11. Jin X., Lian J.S., Hu J.H., Gao J., Zheng L., Zhang Y.M. et al. Epidemiological, clinical and virological characteristics of 74 cases of coronavirus-infected disease 2019 (COVID-19) with gastrointestinal symptoms. Gut. 2020. 69. 1002-9. doi: 10.1136/gutjnl-2020-320926.

12. Guo T., Fan Y., Chen M., Wu X., Zhang L., He T. et al. Cardiovascular implications of fatal outcomes of patients with coronavirus disease 2019 (COVID-19). JAMA Cardiol. 2020. 27. e201017. doi: 10.1001/jamacardio.2020.1017.

13. Yang X., Yu Y., Хu J., Shu H., Xia J., Liu H. et al. Clinical course and outcomes of critically ill patients with SARS-CoV-2 pneumonia in Wuhan, China: a single-centered, retrospective, observational study. Lancet Respir. Med. 2020. 8. 475-81. doi: 10.1016/ S2213-2600(20)30079-5.

14. Хu X.W., Wu X.X., Jiang X.G., Xu K.J., Ying L.J., Ma C.L. et al. Clinical findings in a group of patients infected with the 2019 novel coronavirus (SARS-Cov-2) outside of Wuhan, China: retrospective case series. BMJ. 2020. 368. m606. doi: 10.1136/bmj.m606.

15. Huang C., Wang Y., Li X., Ren L., Zhao J., Hu Y. et al. Clinical features of patients infected with 2019 novel coronavirus in Wuhan, China. Lancet. 2020. 395. 497-506. doi: 10.1016/S01406736(20)30183-5.

16. Chen T., Wu D., Chen H., Yan W., Yang D., Chen G. et al. Clinical characteristics of 113 deceased patients with coronavirus disease 2019: retrospective study. BMJ. 2020. 368. m1091. doi: 10.1136/ bmj.m1091.

17. Koralnik I.J., Tyler K.L. COVID-19: A Global Threat to the Nervous System. Ann. Neurol. 2020. 88. 1-11. doi: 10.1002/ ana. 25807.

18. Mao L., Jin H., Wang M. et al. Neurologic Manifestations of Hospitalized Patients With Coronavirus Disease 2019 in Wuhan, China. JAMA Neurol. 2020. 77(6). 683-690. doi: 10.1001/jamaneurol.2020.1127.

19. Moriguchi T., Harii N., Goto J. et al. A first case of meningitis/ encephalitis associated with SARS-Coronavirus-2. Int. J. Infect. Dis. 2020. 94. 55-58. doi: 10.1016/j.ijid.2020.03.062. 
20. Poyiadji N., Shahin G., Noujaim D., Stone M., Patel S., Griffith B. COVID-19-associated Acute Hemorrhagic Necrotizing Encephalopathy: Imaging Features. Radiology. 2020 Aug. 296 (2). E119-E120. doi: 10.1148/radiol.2020201187.

21. Wong P.F., Craik S., Newman P., Makan A., Srinivasan K., Crawford E., Dev D., Moudgil H., Ahmad N. Lessons of the month 1: a case of rhombencephalitis as a rare complication of acute COVID-19 infection. Clin. Med. 2020. 20(3). 293-294.

22. Zhao K., Huang J., Dai D. et al. Acute myelitis after SARS-CoV-2 infection: a case report. MedRxiv. 2020. doi: 10.1101/2020.03.16.20035105.

23. Sarma D., Bilello L.A. A Case Report of Acute Transverse Myelitis Following Novel Coronavirus Infection. Clin. Pract. Cases Emerg. Med. 2020. 4 (3). 321-323. doi: 10.5811/cpcem.2020.5.47937.

24. Munz M., Wessendorf S., Koretsis G. et al. Acute transverse myelitis after COVID-19 pneumonia. J. Neurol. 2020. 267(8). 21962197. doi: 10.1007/s00415-020-09934-w.

25. Chow C.C.N., Magnussen J., Ip J., Su Y. Acute transverse myelitis in COVID-19 infection. BMJ Case Rep. 2020. 13 (8). e236720. Published 2020 Aug 11. doi: 10.1136/bcr-2020-236720.

26. Valiuddin H., Skwirsk B., Paz-Arabo P. Acute transverse myelitis associated with SARS-CoV-2: A Case-Report. Brain Behav. Immun. Health. 2020. 5. 100091. doi: 10.1016/j.bbih.2020.100091.

27. Palahuta H.V., Yevtushenko S.K. A case of acute myelitis as a neurological complication of COVID-19. International Neurological Journal. 2020. 7 (16). 32-35. (in Ukrainian). doi: 10.22141/22240713.16.7.2020.218244.

28. Lechien J.R. et al. Olfactory and gustatory dysfunctions as a clinical presentation of mild-to-moderate forms of the coronavirus disease (COVID-19): a multicenter European study. Eur. Arch. Otorhinolaryngol. 2020. 1. 11-22.

29. Asadi-Pooya A.A., Simani L. Central nervous system manifestations of COVID-19: A systematic review. J. Neurol Sci. 2020. 413. 116832. doi: 10.1016/j.jns.2020.116832.

30. Zhao H., Shen D., Zhou H., Liu J., Chen S. Guillain-Barré syndrome associated with SARS-CoV-2 infection: causality or coin- cidence? Lancet Neurol. 2020 May. 19 (5). 383-384. doi: 10.1016/ S1474-4422(20)30109-5.

31. Gutiérrez-Ortiz C., Méndez-Guerrero A., Rodrigo-Rey S., San Pedro-Murillo E., Bermejo-Guerrero L., Gordo-Mañas R., de Aragón-Gómez F., Benito-León J. Miller Fisher syndrome and polyneuritis cranialis in COVID-19. Neurology. 2020 Aug 4. 95 (5). e601e605. doi: 10.1212/WNL.0000000000009619.

32. Meegada S., Muppidi V., Wilkinson D.C. $3^{r d}$, Siddamreddy S., Katta S.K. Coronavirus Disease 2019-Induced Rhabdomyolysis. Cureus. 2020. 12 (8). e10123. doi: 10.7759/cureus. 10123.

33. Guo Q., Zheng Y., Shi J. et al. Immediate psychological distress in quarantined patients with COVID-19 and its association with peripheral inflammation: A mixed-method study. Brain Behav. Immun. 2020. 88. 17-27. doi: 10.1016/j.bbi.2020.05.038.

34. Lu S., Wei N., Jiang J. et al. First report of manic-like symptoms in a COVID-19 patient with no previous history of a psychiatric disorder. J. Affect. Disord. 2020. 277. 337-340. doi: 10.1016/j. jad.2020.08.031.

35. Banerjee D., Viswanath B. Neuropsychiatric manifestations of COVID-19 and possible pathogenic mechanisms: Insights from other coronaviruses. Asian J. Psychiatr. 2020. 54. 102350. doi: 10.1016/j. ajp.2020.102350.

36. Fartushna O.Ye., Vinychuk S.M. Tranzytorni ishemichni ataky [Transient Ischemic Attacks]. Kyiv: PH "Avitsena”; 2014. 216 p. (in Ukrainian).

37. Ahmad I., Rathore F.A. Neurological manifestations and complications of COVID-19: A literature review. J. Clin. Neurosci. 2020 Jul. 77. 8-12. doi: 10.1016/j.jocn.2020.05.017. Epub 2020 May 6. PMID: 32409215; PMCID: PMC720036.

38. Hui D.S., Wong K.T., Antonio G.E., Tong M., Chan D.P., Sung J.J. Long-term sequelae of SARS: physical, neuropsychiatric, and quality-of-life assessment. Hong Kong Med. J. 2009. 15. 21-23.

Received 20.12.2020

Revised 30.12.2020

Accepted 08.01.2021

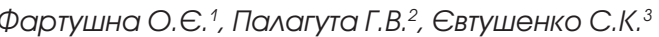

'Українська військово-медична академія, м. Київ, Україна

${ }^{2}$ ¿Аержавний вищий навчальний зак^аА "УжгороАський національний університет», Обласний кАінічний центр нейрохірургії та неврології, м. Ужгород, Україна

ЗХарківська медична акалемія післялипломної освіти, м. Харків, Україна

\section{Неврологічні й нейропсихічні прояви та усклаАнення інфекції SARS-CoV-2: огляA ^ітератури та презентація кАінічного випаАКу в раніше зАорового Аорослого білого чоловіка}

Резюме. Актуальність. 3 виникненням другої хвилі COVID-19 стало очевидним, що новий коронавірус (SARSCoV-2) є широкомасштабним поліорганним захворюванням. Однак неврологічні особливості інфекції COVID-19, особливо в молодих, раніше здорових людей, майже не наведені в літературі. Мета дослідження: надати короткий огляд неврологічних і нейропсихічних проявів та ускладнень COVID-19, підкріплений описом клінічного випадку. Mamepiaлu ma методи. Було проведено всебічний електронний пошук літератури з використанням баз даних Scopus, PubMed, Embase, Cochrane, Всесвітньої організації охорони здоров'я, Ovid та Google Scholar відповідно до бажаних елементів звітності для систематичних оглядів і керівних принципів метааналізу, щоб визначити статті, у яких обговорювалися неврологічні та ней- ропсихічні прояви SARS-CoV-2/COVID-19. Неврологічні прояви та ускладнення COVID-19 ілюструються клінічним випадком у раніше здорової молодої людини білої раси. $\boldsymbol{P e}$ зультати та висновки. Неврологічні та нейропсихічні прояви та ускладнення інфекції SARS-CoV-2 варіюють від легких симптомів, таких як головний біль, до катастрофічних, включаючи делірій, маніакальні епізоди, шизофренію, інсульт, гостру геморагічну некротизуючу енцефалопатію, поперечний мієліт, енцефаліт, менінгіт, синдром Гієна - Барре. Ми навели огляд неврологічних та нейропсихічних проявів та ускладнень інфекції SARS-CoV-2, проілюстрований клінічним випадком. Ключові слова: COVID-19; SARS-CoV-2; гострий мієліт; неврологічні прояви; нейропсихічні прояви; ускладнення; клінічний випадок; огляд 
Фартушная E.E.', Палагута А.B. ${ }^{2}$, Евтушенко C.K. ${ }^{3}$

'Украинская военно-медицинская академия, г. Киев, Украина

2Государственное высшее учебное заведение “Ужгородский национальный университет», Областной клинический центр нейрохирургии и неврологии, г. УжгороА, Украина

зХарьковская медицинская акаАемия послеАипломного образования, г. Харьков, Украина

\section{Неврологические и нейропсихические проявления и осложнения инфекции SARS-CoV-2: обзор ^итературы и презентация кАинического случая у ранее зАорового взрослого белого мужчины}

Резюме. Актуальность. С возникновением второй волны COVID-19 стало очевидным, что новый коронавирус (SARSCoV-2) является широкомасштабным полиорганным заболеванием. Однако неврологические особенности инфекции COVID-19, особенно у молодых, ранее здоровых людей, практически не описаны в литературе. Цель исследования: предоставить краткий обзор неврологических и нейропсихических проявлений и осложнений COVID-19, подкрепленный описанием клинического случая. Материалы и методы. Был проведен всесторонний электронный поиск литературы с использованием баз данных Scopus, PubMed, Embase, Cochrane, Bceмирной организации здравоохранения, Ovid и Google Scholar в соответствии с предпочтительными элементами отчетности для систематических обзоров и руководящими принципами метаанализа, чтобы определить статьи, в которых обсуждались неврологические проявления SARS-CoV-2/COVID-19.
Неврологические проявления и осложнения COVID-19 иллюстрируются клиническим случаем у ранее здорового молодого человека белой расы. Результаты и выводы. Неврологические и нейропсихические проявления и осложнения инфекции SARS-CoV-2 варьируют от легких симптомов, таких как головная боль, до более выраженных, включая делирий, маниакальные эпизоды, шизофрению, инсульт, острую геморрагическую некротизирующую энцефалопатию, поперечный миелит, энцефалит, менингит, синдром Гийена - Барре, а также многие другие. Мы представили описательный обзор неврологических и нейропсихических проявлений и осложнений инфекции SARS-CoV-2, подкрепленный клиническим случаем.

Ключевые слова: COVID-19; SARS-CoV-2; острый миелит; неврологические проявления; нейропсихические проявления; осложнения; клинический случай; обзор 